\title{
Resilience and transformation of heritage sites to accommodate for loss and learning in a changing climate
}

\author{
Erin Seekamp ${ }^{1}$ (D) Eugene Jo ${ }^{2}$
}

Received: 14 January 2020 / Accepted: 28 July 2020/Published online: 7 August 2020

(C) The Author(s) 2020

\begin{abstract}
The predicted increases in climate change vulnerability of heritage sites are alarming. Yet, heritage management focuses on enabling a steady state of heritage sites to ensure the continuity of values embedded within those properties. In this paper, we use the concept of resilience to demonstrate how expanding the heritage paradigm from solely a preservation perspective to one that also embraces a transformation perspective can accommodate for loss as well as promote learning. We argue that adaptation as currently conceptualized in the heritage field is limited, as it is not economically or ecologically feasible for all heritage sites or properties. When heritage properties are severely impacted by climatic events, we suggest that some remain damaged to serve as a memory of that event and the inherent vulnerabilities embedded in places. Moreover, when confronted with projected climatic impacts that exceed a financially viable threshold or ecological reality, or when rights holders or associated communities deem persistent adaptation unacceptable, we argue for transformation. We claim that transformation enables a reorganization of values focused on the discovery of future values embedded within changing associations and benefits. Therefore, we recommend that the heritage field adopts an alternative heritage policy that enables transformative continuity through applications of persistent and autonomous or anticipatory adaptation. We conclude by suggesting a pathway for such change at the international level; specifically, we call for the World Heritage Convention to develop a new grouping of sites, World Heritage Sites in Climatic Transformation.
\end{abstract}

Keywords Climate change $\cdot$ Heritage management $\cdot$ Continuity $\cdot$ World heritage

Erin Seekamp

elseekam@ncsu.edu

Eugene Jo

ej@iccrom.org

Extended author information available on the last page of the article 


\section{Introduction}

Climate change threats to heritage properties are increasingly being studied (Fatorić \& Seekamp 2017a), invoking national- and international-level responses. For example, the U.S. National Park Service's published report, "Cultural Resources Climate Change Strategy," not only provides guidance for adaptation but also succinctly summarizes the impacts of temperature change, precipitation change, sea level rise, increased greenhouse gas emissions on archeological resources, cultural landscapes, ethnographic resources, museum collections, and buildings and structures (Rockman et al. 2016). The International Council on Monuments and Sites' (ICOMOS) report, "The Future of Our Pasts: Engaging Cultural Heritage in Climate Action," provides a multidisciplinary overview of the intersection of cultural heritage and climate change (ICOMOS 2019).

The prestige of World Heritage site designation has drawn the attention of scholars working at the intersection of heritage and climate change. For example, Perry (2011) identified the most at-risk natural World Heritage (WH) sites, and Marzeion and Levermann (2014) assessed coastal cultural WH sites vulnerable to sea level rise. Most recently, Guzman et al. (2020) documented the increasing prevalence of climate change as a threat within the WH monitoring system (i.e., State of Conservation (SOC) reports). Simultaneously, there has been an emerging trend within critical heritage studies to critique climate change concerns for heritage only in relation to tangible, physical resource (and the patriarchal policies that designated that heritage), rather than the active and dynamic role of heritage values that provide meaning and are manifested in tangible attributes (DeSilvey 2017; Krauß 2015; Lafrenz Samuels 2018). Yet, few concrete pathways for substantive change have been offered to provide policy guidance.

In this opinion paper, we suggest that a focus on heritage resilience can create a policy window that embraces both the traditional preservation paradigm and the emerging transformation paradigm. We argue that policy reform is needed to create flexibility that allows for both the continuity of heritage values and the evolution of place meanings and societal benefits in face of climate change. Specifically, we focus our discussion around the concept of resiliency from the engineering and ecology disciplines, and how adaptation strategies can maintain or transform heritage values. We operationalize resilience as the ability for heritage values to recover (engineering and ecological disciplines) or transform (ecological discipline) following climate change impacts. Additionally, we argue that policy change could enable two distinct "learning from loss" moments: (a) in the aftermath of impacts that severely damage sites (b) through the proactive cultivation and transformation of heritage values that enable the discovery of future heritage values within rapidly changing sites. Thus, the concept of transformative continuity in relation to time and memory becomes defining aspects of policy change, and we use the United Nations Educational, Scientific and Cultural Organization (UNESCO) World Heritage List and the List of World Heritage Sites in Danger to exemplify the limitations of a strictly preservationist policy.

We use UNESCO's World Heritage (WH) system as the policy example given ongoing efforts by UNESCO's World Heritage Center, the International Union for Conservation of Nature (IUCN), the International Centre for the Study of the Preservation and Restoration of Cultural Property (ICCROM), and ICOMOS to both (a) raise awareness of climate change threats to natural and cultural heritage (e.g., Colette 2007; Markham et al. 2016) and (b) develop management guidance for adaptation (e.g., Perry \& Falzon 2014) and risk management (e.g., UNESCO 2010). We focus on WH sites that can be considered socio-ecological systems and can be considered (even if not originally listed as) cultural landscapes, with 
tangible and intangible heritage resources, rights holders' or traditionally associated communities' values of and relationships to the resources, and broader societal benefits. Moreover, we select the WH system as the policy context due to the nationalistic prestige associated with inscription and associated political maneuvering (e.g., political blocs), along with the inadequate fiscal support for monitoring, that make the intention of the List of World Heritage Sites in Danger an undesirable and, therefore, ineffective way to deal with threats, including climate change (Meskell 2013, 2014). We argue that rather than including such sites on the List of World Heritage Sites in Danger, the WH Convention should take a proactive management approach by grouping them in a new type of recognition category, such as World Heritage Sites in Climatic Transformation, to address some of the current shortcomings that make it virtually infeasible to address climate change threats and promote a new understanding of the resilience and continuity of heritage values. To help elucidate our arguments, we not only describe the complexity of challenges facing WH sites, using Venice as an example, but also describe examples of inspirational approaches at non-WH sites, using Ninfa Gardens as an example.

\section{Adaptation of heritage}

The prevalence of climate change impact monitoring at heritage sites is increasing, particularly at natural heritage sites within the WH system (Guzman et al. 2020). Additionally, researchers are documenting the constraints associated with adapting heritage sites to changing climatic conditions (Fatorić \& Seekamp 2017b; Sesana et al. 2018), as well as providing decision guidance by assessing the vulnerability of heritage sites (e.g., Reeder-Meyers 2015; Reiman et al. 2018), measuring the significance of heritage sites (e.g., Fatorić \& Seekamp 2018; Mendes Zancheti \& Tone Ferreira Hidaka 2011), or integrating both (e.g., Carmichael et al. 2018; Heilen et al. 2018; Xiao et al. 2019). However, studies that document the success or failure of adaptation actions in maintaining heritage values are needed (Fatorić \& Seekamp 2017b; Rockman et al. 2016). Unfortunately, the challenge here is that "adaptation is often a blind process that can be viewed as 'rational' only in hindsight" (Thornton \& Manasfi 2010, p. 133), and the potential for adaptation actions to negatively impact associated communities' values of heritage properties and connections to heritage sites is emerging in the literature (e.g., Henderson \& Seekamp 2018).

As the heritage field transitions from the conservation of objects and monuments to both tangible and intangible resources with a focus on traditionally associated communities' values and broader societal values, there is recognition of heritage as a vector within socio-ecological systems that are reflective of the social layering of heritage (Janssen et al. 2017) and that heritage values and identity are drivers of landscape change (Tengberg et al. 2012). In fact, UNESCO, in their sustainable development policy guidance, recognizes the socio-ecological links and interdependencies that "have often developed over time through mutual adaptation between humans and the environment, interacting with and affecting one another in complex ways, and are fundamental components of the resilience of communities" (UNESCO 2015, p. 3). As such, heritage scholars are musing about the need to rethink the traditional preservationist paradigm (i.e., the static state conservation of tangible heritage attributes) and its associated policies given projected impacts to tangible heritage resources and intangible values, the diverse and dynamic manifestations of those values, and the likelihood of loss from changing climatic conditions (e.g., Barnett et al. 2016; DeSilvey 2017; Harvey \& Perry 
2015; Krauß 2015; Lafrenz Samuels 2018). Here, we argue that the heritage field adopt an ecological framework of resilience to expand the preservationist paradigm in a way that enables persistent adaptation (continuity of heritage in a static state), anticipatory adaptation (continuity of heritage through planned change), and autonomous adaptation (continuity of heritage through changing values).

\section{The concept of resilience in heritage}

The resilience theory has emerged from two distinct fields, engineering and ecology, with distinct interpretations (Holling 1996). The engineering field focuses on the resistance to and recovery from disturbances that threaten the functional stability of a system, and measures resilience as the amount of time needed to return to an optimal and stable state (Gunderson et al. 2002). This theory of resilience conforms to current heritage policy, with a focus on continuity of values - specifically, outstanding universal value (OUV) or values described within a WH property's Statement of Significance, or some combination thereof - at the time of inscription. When disturbances negatively impact these values to surpass some threshold (note: thresholds are currently not well-defined as it cannot be unilaterally applied to the diverse types of heritage that the World Heritage Convention recognizes), then a property is moved (at least theoretically) to the List in Danger (Fig. 1). In a climate change context, this understanding of resilience equates adaptation as necessary to maintaining values at the time of inscription, regardless of changing socio-ecological conditions or changing values, place meanings, or societal benefits. As such, adaptation actions are implemented when monitoring (e.g., State of Conservation documentation cycle) indicates that the inscription values are currently or projected to be negatively impacted. This type of adaptation focuses on the persistence and preservation of values to a specified time in our collective memory.

It is important to note that we are not necessarily stating that this preservationist perspective on resilience is not a valid approach for some WH properties; rather, we are explicitly acknowledging that the accumulation of heritage makes preservation of all WH system values in perpetuity fiscally impossible. Moreover, we are acknowledging a concern for system rigidity that occurs when the agency of actors within the system is suppressed by limiting

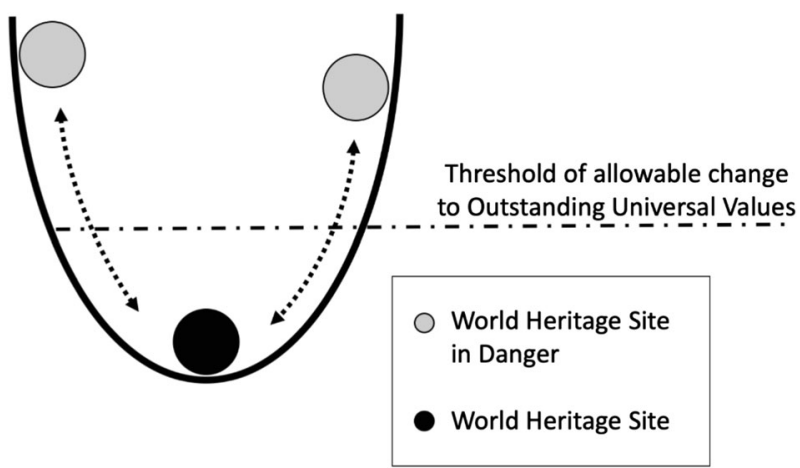

Fig. 1 Resilience theory informed by an engineering perspective that replicates the heritage preservation paradigm (ball-and-cup heuristic, where the ball is the state of the WH site's values and the cup is the socioecological system in which the WH site is located; adapted from Holling 1996; Holling et al. 2002) 
their possible behaviors (Bocinsky \& Kohler 2016) and, within a climate change context, can result in unanticipated or unprecedented losses (Rotherham 2013). For example, how many times will residents of historical homes and museum administrators in Venice, Italy - a World Heritage site - continue to invest in restoration after flooding ${ }^{1}$ before they simply abandon the city? How are these residents' place meanings altered following flooding events and how would elevating their homes, if it is even possible in a sinking city, affect their place connections and the OUVs of Venice? Currently, the MOSES Project appears to be the only viable adaptation option ... but will it actually work and for how long will it extend the OUVs of Venice (if they have not already been fully compromised by the other key threat: mass tourism ${ }^{2}$ )? What happens to Venetians' sense of place if the lagoon becomes stagnant and algal blooms negatively impact the local fisheries? Given the limitations of this preservationist approach to resilience, we argue that persistent adaptation (Folke et al. 2010), which promotes innovation through strategies for revitalization in response to actual or expected climate impacts, is not the only option.

Resilience from an ecological framework expands the preservationist paradigm in a way that enables both reactive, persistent adaptation and planned, anticipatory adaptation. Although Holling (1973) originally conceptualized ecological resilience in a paradigm of nonequilibrium that focuses on the ability to absorb disturbance and still persists, Walker et al. (2004) explain that the ecological resilience concept has evolved to acknowledge the nonlinear stability of socio-ecological systems. This expanded view of system stability accepts that some disturbances result in regime shift or transformation to a new state dominated by reorganization. As such, the ecological theory of resilience creates an opportunity to anticipate catastrophic climatic events that are outside of a WH property's current socio-ecological system's threshold and to plan for the reorganization of heritage values to enable their transition (Fig. 2).

In this paper, we claim that persistent adaptation places a focus on innovation through regeneration of heritage values following degradation or destruction from climate change effects. Innovation here revolves around developing and implementing tools, technologies, and materials that maintain or restore the tangible heritage assets that convey the original values with minimal detectable change. Conversely, we claim that anticipatory adaptation places a focus on innovation through the planned transformation of heritage values prior to climate change effects. Innovation here revolves around developing and implementing tools, technologies, and materials that reduce the sensitivity of the tangible heritage assets or reduce the exposure of them to climate change effects, while explicitly recognizing that in doing so requires the transformation of some heritage values. Moreover, we claim that this heritage as a transformation paradigm also enables autonomous adaptation (Smit et al. 2001) following unanticipated or profound disturbances (i.e., catastrophic single hazard events or rapidly changing environmental or climatic conditions), which enables innovation through, for

\footnotetext{
${ }^{1}$ For example, the 2018 floods were reported to cause St. Mark's Cathedral to age 20 years in 1 day, according to popular press articles, such as Provoledo, E. (October 30, 2018). Venice flooding is worst in a decade. Severe weather in Italy kills at least 11. The New York Times. Accessed on August 13, 2019, from https://www.nytimes. com/2018/10/30/world/europe/venice-floods-italy.html. And, the 2019 floods are likely the highest water levels in 50 years with the worst week of repeated flooding since flood records began in 1872 and damages estimated at Euro 1 billion (France-Presse, A. (November 17, 2019). Venice closes St. Mark's Square as floods hit for third time in week. The Guardian. Accessed on December 4, 2019, from https://www.theguardian.com/world/2019 /nov/17/venice-closes-st-marks-square-as-high-water-threatens-again).

${ }^{2}$ For a more thorough discussion of the challenges facing Venice, see Settis (2016). If Venice dies. New York, New York: New Vessel Press.
} 


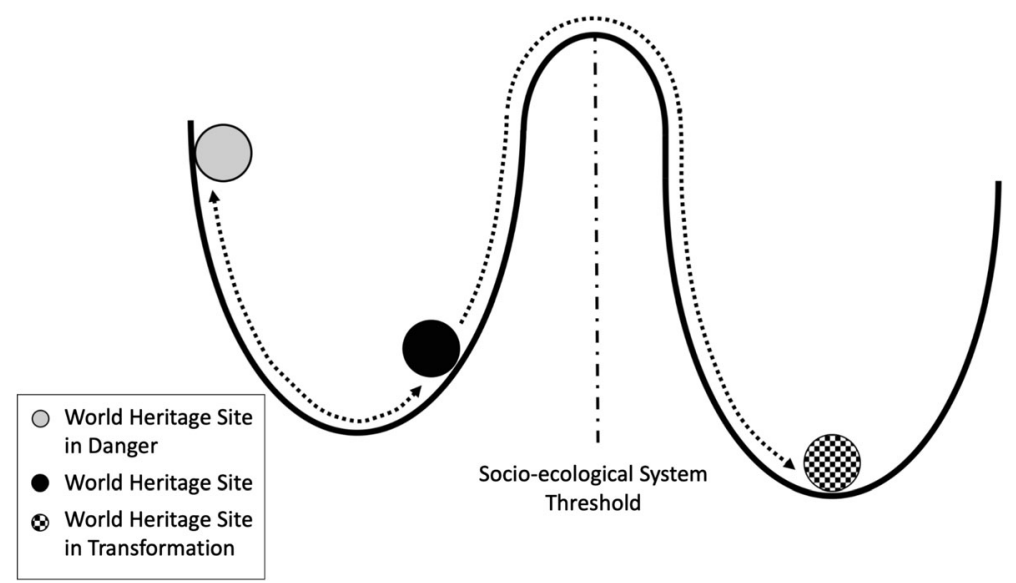

Fig. 2 Resilience theory informed by an ecological perspective that advances a heritage transformation paradigm (ball-and-cup heuristic, where the ball is the state of the WH site's values and the cup is the socio-ecological system in which the WH site is located; adapted from Holling 1996; Holling et al. 2002)

example, the transformation of tangible heritage assets to intangible heritage aspects. Innovation here revolves around the transferability of heritage values as defined and developed by the legal and proximate communities during the response to rapid change and without the typical policy constraints imposed by external actors.

Thorton and Manasfi (2010) explain that autonomous adaptation is often overlooked or downplayed because of the tendency for techno-fix solutions to projected climate change impacts (e.g., MOSES Project). These authors argue that autonomous adaptation allows locally driven responses to profound disturbances and that such responses often foster the innovation and revitalization necessary to support cultural adjustments to changing conditions. With the transitions in international WH guidance to include "living heritage" or "people-centered" approaches (ICCROM 2015; Wijesuriya et al. 2017), embracing an ecological resilience framework seems logical to ensuring the continuity of heritage values within $\mathrm{WH}$, as continuity ${ }^{3}$ recognizes the "continuous process of evolving tangible and intangible heritage expressions in response to changing circumstances - in this sense, change is embraced as a part of the continuity" (Poulios 2014, p. 21). The evolution of WH management from top-down to bottom-up approaches demonstrates the linked multiscalar interactions-both through time and levels of governance (i.e., panarchy; Gunderson \& Holling 2002) - influencing socio-ecological systems and the evolution of values and place meanings in ways that honor the rights of local peoples to imagine the changes in the material fabric of tangible heritage that best manifest their heritage values. As such, we contend that WH sites' resilience - in the face of climate change- benefits by temporal and spatial transformative continuity.

\footnotetext{
${ }^{3}$ Poulios (2014) explains that continuity also includes "the continuity of the heritage's original function - the purpose for which heritage was originally intended; the continuity of community's connection with heritage; the continuity of the care of heritage by the community as expressed through (traditional) knowledge, management systems, and maintenance practices" (p. 21).
} 


\section{The concept of transformative continuity}

Transformative continuity is a seldom used, but apt, concept within the heritage field, emerging out of historical-ethnographic studies of indigenous social structures and cosmologies in relation to the "relative dynamism and power of interacting local and global forces" (i.e., structuration) (Clifford 2000, p. 102). For example, Laugrand and Crépeau (2015) explain how globalization and indigenous societies transform shamanism from the dominant system to a key domain that mobilizes concepts of force, energy, and power "to affirm the precedence of certain notions in humans' relations with nature or to defend cultural ideals when managing natural resources or preserving ancestral territories" (p. 291). Here, we conceptualize transformative continuity as the ability to carry forth aspects of cultural landscapes - in particular, tangible and intangible heritage, cultural values and relationships to places, and societal benefits - regardless of whether or not they are restored through persistent adaptation or if they are rearranged through anticipatory or autonomous adaptation into new cultural landscapes following disturbances (Fig. 3). In other words, we claim that transformative continuity acknowledges that cultural landscapes are continually reconstructed. ${ }^{4}$

We use memory and discovery as metaphors to describe diverse approaches to climate adaptation of WH properties throughout various moments of transformation, starting when a WH has been disturbed, which we contend is an imperative moment for decision-making. We argue that the initial transformation of aspects within a disturbed cultural landscape serves a moment in which some of those climate impacts and their associated vulnerabilities could be preserved to demonstrate a tangible and sacred memory of the associated socio-ecological vulnerabilities embedded within specific geographical locales. Similar to other imperative moments, such as places of genocide (for a review, see Butler 2006) and "negative heritage" sites where heritage properties are destroyed or created by conflict (Meskell 2002), there is a precedent for the preservation of "heritage as memory" when sites are impacted by natural hazards and climate change impacts, as they not only transfer the memory of change but also can serve as a disaster mitigation measure (Nishikawa, n.d.). We also argue that heritage not only enables remembering "the meanings and representations placed upon the past in the present" (Graham 2011, p. 94), but also supports a process of continuous memory formation in which people can shape and discover new meanings through the negotiation of present and future values and identities as cultural landscapes transform.

The potential for discovery with anticipatory and autonomous adaptation in WH properties undergoing transition from climate change effects can also promote "transformational learning" (Mezirow 1991) by enabling ongoing reflection — or remembering — of the lived experience and relationships to natural and cultural heritage. According to transformational learning theory, individuals interpret and reinterpret their experiences to make meaning beyond just simple knowledge acquisition that guides future action (Mezirow 1991), which can directly shape adaptation decisions. When explicitly engaged in heritage planning and decisionmaking, communities can interpret and reinterpret their resilience, while focusing on their values, cultural traditions, assets, and capabilities through facilitated reflection. As such, transformative continuity can be an ongoing process of remembering and discovering that can promote any type of adaptation (i.e., persistent, anticipatory, or autonomous) and one that

\footnotetext{
${ }^{4}$ The idea of cultural landscapes being continually reconstructed is an idea embedded within the 2008 Quebec Declaration on the Preservation of the Spirit of a Place (ICOMOS, 2008). For a thorough discussion of this idea in relation to continuity and rhizomatic preservation guidance for genius loci sites, see Markevičienè (2012).
} 


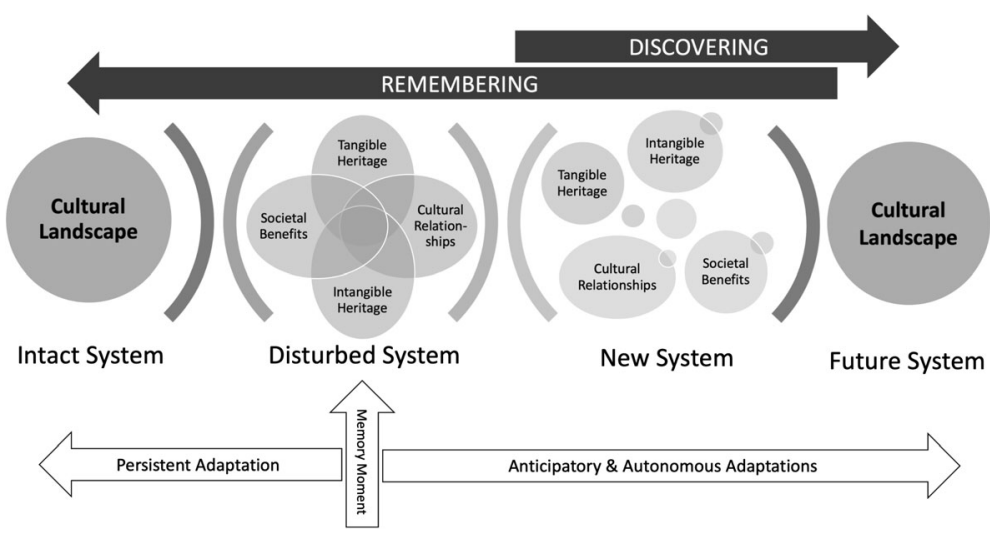

Fig. 3 Transformative continuity, adaptation, and the roles of memory and discovery

promotes continuous memory reflection during various stages of climate adaptation planning and response. Moreover, enabling transformation of WH properties threatened or impacted by climate change could be a strategy to open "ourselves up to a more meaningful and reciprocal relationship with the material past” (DeSilvey 2017, p. 179).

\section{The need for policy change}

Currently, sites with OUVs or the conditions of integrity and authenticity at the time of inscription $^{5}$ threatened by climate change effects could be inscribed to the List of World Heritage Sites in Danger (hereafter, "Danger List") and eventually may be delisted (Markham et al. 2016). Originally conceptualized as a conservation tool, a site that is added to the Danger List would spur management action and support from the World Heritage Fund (Meskell, 2013). Yet, there are few instances in which countries deem the Danger List to be a positive outcome regardless of the rationale, such as the Everglades in which the USA has twice asked for degraded listing. ${ }^{6}$ More frequently, States Parties interpret the Danger List as an undesirable situation that would result in loss of tourism revenue. For example, according to a news story by Michael Slezak ${ }^{7}$ that appeared in the Guardian following the release of UNESCO's "World Heritage and Tourism in a Changing Climate" report (Markham et al., 2016), all references to climate change effects on World Heritage sites in Australia were removed from the document.

\footnotetext{
${ }_{5}$ Integrity typically refers to the intactness or wholeness of all the critical elements of a site, while authenticity typically refers the truthfulness and credibility of the cultural values embedded within a property's form and design, materials and substance, and location and setting, or within the intangible function, tradition, and spirit (Jokilehto 2006); for a thorough review of the challenges of managing and protecting the integrity and authenticity of WH sites, see Alberts and Hazen (2010).

${ }^{6}$ Chase, A. (August 9, 2010). Everglades National Park added to List of World Heritage in Danger. Natural Resource Defense Council (NRCD) Expert Blog. Last accessed August 12, 2019, from https://www.nrdc. org/experts/alison-chase/everglades-national-park-added-list-world-heritage-danger

7 Slezak, M. (May 26, 2016). Australia scrubbed from UN climate change report after government intervention. The Guardian. Last accessed August 12, 2019, https://www.theguardian.com/environment/2016/may/27 /australia-scrubbed-from-un-climate-change-report-after-government-intervention.
} 
Also, compounding concerns for having sites degraded to the Danger List are the woefully inadequate amount of fiscal support available to assist States Parties to support site management (of any kind) from the World Heritage Fund (Markham et al. 2016). As such, it seems that, unless persistent adaptation is funded by external partners or a States Party - and that the persistent adaption does not negatively impact the integrity and authenticity of the site 8 - the inevitable and ultimate outcome would be delisting. We believe that such a fatalistic approach could undermine the World Heritage Convention. Moreover, we believe that policy changesuch as creating a new category of a site grouping for those already inscribed on the WH List, for the purposes of managing change - could accommodate transformative continuity, adaptation, and the roles of memory and discovery through this era of climatic change, while also (a) being more appealing to States Parties and (b) aligning to the calls for more inclusive and people-focused approaches to heritage conservation and management (e.g., Larsen 2018).

We argue that the WH Convention needs to take a proactive lead in setting new groupings for addressing complex management challenges, not just installing categories for the purposes of inscription. In doing so, it would expand its role as an instrument focusing on the protection of the listed sites rather than solely on the continual addition of new sites. For example, the original focus of WH sites was distinctly on "natural heritage," "cultural heritage," or "mixed sites"; yet, a broader understanding of living heritage and the interrelationships between people and the environment was adopted with the inclusion of "cultural landscapes" in 1992 (Rössler 2006). In fact, within the definition of cultural landscapes, there is the possibility to define a site as an organically evolving landscape, which would allow for anticipatory and autonomous adaptation. As such, the WH Convention emulates the idea of transformative continuity in its acceptance of evolving understandings of heritage and should recognize management practices that allow for all forms of adaptation to address climatic change. Therefore, it seems both logical and plausible that the WH Convention could be open to developing new categories of site typologies, such as it has been with the adoption of the Small Islands Developing States (SIDS) thematic approach to a portion of listed WH sites. ${ }^{9}$

Here, we are suggesting a new thematic grouping-World Heritage Sites in Climatic Transformation - to accommodate changing cultural values and relationships with and societal benefits derived from a WH site. Such policy reform would also reflect contemporary claims that heritage is a dynamic, evolving process (rather than a static product) made by scholars such as Khalaf (2017), Labadi (2013), and Smith (2006). Additionally, a World Heritage Sites in Climatic Transformation grouping would enable the creation of a database of climate change-affected sites classified by actions and impacts (expanding the current State of Conservation database), providing valuable management guidance about how to recognize threats, adaptation strategies, and the outcomes of those adaptation strategies. Any climateinduced changes in WH site conditions and values - both OUVs and local values - would ideally be captured in the WH Convention's Periodic Reporting (6-year cycles) mechanism and adaptation strategies implemented updated through its Action Plans.

\footnotetext{
${ }^{8}$ For a thorough discussion about the roles of integrity and authenticity in policy reform for reconstruction of sites threatened by conflict, see Khalaf (2017).

${ }^{9}$ Although we are using SIDS as an example, the SIDS thematic grouping have dedicated Action Plans to boost the development and implementation of World Heritage-related activities which have yet to go through an analytical evaluation to collect the results stemming from the action. However, having a dedicated focus on SIDS has enabled the ability to trigger tangible management actions at SIDS WH sites, which is in line with our proposal of establishing a separate grouping for climate change-affected sites.
} 
Our suggested values-focused approach would be one that accommodates transformative continuity and provides guidance about diverse climate adaptation options, not prescriptive adaptation pathways. Additionally, our intention is not merely to address the issue of climate change, but rather utilize the issue of climate change to draw attention to the transformative aspects of heritage values within the World Heritage Convention. Properties that are affected by other sudden disasters (e.g., earthquakes, tsunamis, or volcanic eruptions) could also benefit from this approach, as site managers would face similar difficult choices in selecting methods to "recuperate" from the sudden change. We argue that the fact that almost all sites will eventually be affected by climate change not only highlights the importance of recognizing transformative continuity for addressing heritage conservation and management, but also provides the necessary leverage for policy reform. Our hope is that such policy reform addresses transformation pathways not only for sudden and gradual climatic change impacts, but also for other unanticipated natural disasters.

Increasingly, management guidance for WH sites recommends a more descriptive "statement of significance" (in addition and complementary to the Statement of OUV ${ }^{10}$ ) to document the overall values of a WH site (UNESCO/ICCROM/ICOMOS/IUCN 2013; ICOMOS 2011). Such a statement could include the relative importance of the cultural and natural heritage values of a WH site, the interdependencies between the attributes that embody those values, the existing heritage value conflicts, other external threats to the heritage attributes and values, and the local and communal values that may not necessarily justify inscription but should be included to enhance their legitimacy as management considerations. We suggest that, for the new group of sites, the transformative features as well as a form of adaptation visioning should be included in the statement of significance in relation to the attributes and values included in the Statement of OUV (SOUV), where regular updates can be made to the Protection and Management section of the SOUV as attributes - and their associated and interdependent values - begin to change following adaptation, climatic events, or both. ${ }^{11}$

For multiple forms of adaptation to be recognized and considered an option, mechanisms need to be inserted into the regular working procedures of the WH Convention. A separate group listing of sites that recognizes the transformative changes at the forefront can be a policy-level catalyst to change the business-as-usual approach. Specifically, to consider not only the OUV that justifies its place on the WH List but also the integral, holistic, and dynamic values that need to be considered for management and conservation, enables inclusion of mutable global and local values of the site and the transformation of tangible and intangible manifestations of those values. Thus, adopting the practice of developing the "statement of significance" can invoke a change in the operational actions of the WH Convention in approaching management and, subsequently, affect management practices implemented at the site level. This type of approach would enable not only transformative continuity but also a focus on learning through discovery that uses people-centered approaches to focus on the documentation and interpretation — and, possibly, celebration — of change. Moreover, it is this

\footnotetext{
${ }^{10}$ Statement of OUV (SOUV) is the official text adopted by the WH Committee at the time of inscription and something that defines the site values that merit its place on the WH List through comparative analysis and multiple evaluations. "Statements of significance" temporarily existed within the WH system but currently is not officially recognized in the World Heritage Convention's Operational Guidelines.

${ }^{11}$ We would like to point out that a reviewer indicated that some "natural" WH sites, like the Jurassic Coast WH Site (UK) (see Harvey 2012; Ferraby 2015), include "environmental change" in the state OUV; yet, within the WH Convention, such acceptance of transformation is not typical with stated OUVs of "cultural" WH sites.
} 
learning through discovery that could enable the transformation of a site's intrinsic values to become the exceptional "issue" or "theme" of a site and maintains the universal and extraordinary status of the site, creating continuity in the wholeness or integrity of the site and its authenticity. ${ }^{12}$

Scholars are already suggesting that we should be discovering how past societies responded to rapid environmental and climate change. As Lafrenz Samules (2018) documented, such archeological evidence will help us better understand "the dynamics of sustainability and collapse (e.g., Cooper \& Sheets 2012; Middleton 2012; McAnany \& Yoffee 2010), as well as targeted examples of local adaptations, vulnerabilities, or cultural resilience (e.g., Cline, 2015; Dugmore et al. 2007; Fisher et al., 2009; Hald 2009; Turney et al. 2006; Yaeger \& Hodell 2008)" (p. 89). Here, we are suggesting that allowing WH sites to transform can also serve as evidence of how contemporary societies respond to rapid environmental change and transition following climate change. Yet, extensive (and likely expensive) coordination-between the people who have "rights" and relationships to a site, other groups of people who value the various attributes of a site, site managers, States Parties, and other stakeholders in the boundary zones, as well as for ongoing monitoring of changes to tangible and intangible resources and their associated cultural values - will be required for properties grouped as World Heritage Sites in Climatic Transformation. Unfortunately, it is unlikely that WH Fund can support any of these efforts, not only because the fund was designated to protect static OUVs from change but also due to the limited amount of fiscal resources within the fund. Moreover, WH site managers are already facing fiscal and capacity barriers to protecting sites (Watson et al. 2014). Therefore, a new type of funding program - perhaps one built around strategic and targeted philanthropic donations - is required to provide the types of supports necessary to enable transformational planning and implementation for sites grouped as World Heritage Sites in Climatic Transformation.

\section{Conclusion}

In the transformation of heritage properties, a logical path towards a new system could be palliative curation. As described by DeSilvey (2017), palliative curation focuses on preparing heritage sites for transformation by taking measures - but only those that are of "minimal intervention" (p. 160) - to ease the transition of values from what has been known to what can become, overcoming the tendency for continual investment in maintenance and last-ditch efforts to prolong the inevitable. Such an approach would necessitate intentional decisionmaking to enable what DeSilvey (2017) suggests is the "mobility of memories," as we argue that mobility can only be deemed appropriate by a heritage property's associated community(s). In cases where the movement of materials is deemed detrimental to place meanings, monitoring the changes to a heritage property and its associated cultural meanings and societal benefits will enable discovery within evolving landscapes. This latter approach is similar to Poulios' $(2010,2014)$ concept of "living heritage" in which "heritage can be continually renewed if the social relations and practices that give it meaning are sustained over time, even if the associated material fabric is substantially altered or erased" (DeSilvey 2017, p. 185).

${ }^{12}$ For a review of the concepts of universality, integrity, and authenticity in the WH system, see Jokilehto (2006). 
The heritage site Ninfa Gardens (not inscribed on the WH List) in Cisterna di Latina, Italy, exemplifies such transformation and a renewed living heritage. From a medieval walled city that was destroyed and abandoned in the 1300s, Ninfa Gardens was transformed in the 1900s to a place where nature - both plants and water - is curated among the ruins of its buildings and walls. The experience of visiting Ninfa is not one of lost heritage values within the ravaged and neglected city but one of honoring its memory while allowing new values to take root in the unique and non-traditional garden designs that celebrate the ruins in a patchwork of colors and sounds. It invokes a uniquely different, but not less outstanding, experience than heritage sites devoid of the inclusion of values in transition. Although Ninfa Gardens' transformation was not a product of climatic change, it serves as a lesson for re-thinking the traditional preservationist paradigm within heritage policy. ${ }^{13}$

In summary, to accommodate various forms and stage of transformation of heritage in an era of climatic change, changes in preservation policy are needed. We suggest that the heritage field adopts the ecological framework of resilience, as it provides a comprehensive approach to adaptation that enables not only a focus of remembering heritage values through persistent adaptation (preservationist paradigm) but also a focus of discovering transitioning heritage values through anticipatory and autonomous adaptation (transformation paradigm). Additionally, when sites are actually disturbed from climate change impacts, there is also a moment of opportunity to celebrate and conserve the memory of disturbance by not adapting an impacted site. However, the coordination required to enable transformation and the costs of adaptation are beyond the scope of current capabilities and mechanisms. We contend that policy change is the starting place to address these challenges, even though it may be ontologically challenging for heritage professionals. At the international level, we recommend adopting a new type of site grouping within the WH system, such as a World Heritage site in Climatic Transformation, that can accommodate the transformative continuity of tangible and intangible resources, cultural values and relationships to sites, and broader societal values. As procedural matters take time, our suggested pathway of thematic groupings of WH sites in Climatic Transformation, with the creation of a database of sites experiencing such change, begins to address the threats to WH sites from climate change now.

Open Access This article is licensed under a Creative Commons Attribution 4.0 International License, which permits use, sharing, adaptation, distribution and reproduction in any medium or format, as long as you give appropriate credit to the original author(s) and the source, provide a link to the Creative Commons licence, and indicate if changes were made. The images or other third party material in this article are included in the article's Creative Commons licence, unless indicated otherwise in a credit line to the material. If material is not included in the article's Creative Commons licence and your intended use is not permitted by statutory regulation or exceeds the permitted use, you will need to obtain permission directly from the copyright holder. To view a copy of this licence, visit http://creativecommons.org/licenses/by/4.0/.

\section{References}

Alberts HC, Hazen HD (2010) Maintaining authenticity and integrity at cultural world heritage sites. Geogr Rev 100(1):56-73

\footnotetext{
${ }^{13}$ It is also worthy of mentioning that Ninfa Gardens' management focuses on the protection of the heritage assets, rather than the exploitation of them, by limiting public access to avoid visitor impacts. As such, Ninfa Gardens also serves as an example for transforming traditional tourism management — an important topic but one that is beyond the scope of this paper.
} 
Barnett J, Tschakert P, Head L, Adger WN (2016) A science of loss. Nat Clim Chang 6(11):976

Bocinsky RK, Kohler TA (2016) Complexity, rigidity, and resilience in the ancient Puebloan Southwest. In: Foster HT II, Paciulli LM, Goldstein DJ (eds) Viewing the future in the past: historical ecology applications to environmental issues. University of South Carolina Press, Columbia, pp 86-105

Butler B (2006) Heritage and the present past. In: Tilley C, Keane W, Küchler S, Rowlands M, Spyer P (eds) Handbook of material culture. Sage, London, pp 463-479

Carmichael B, Wilson G, Namarnyilk I, Nadji S, Brockwell S, Webb B et al (2018) Local and Indigenous management of climate change risks to archaeological sites. Mitig Adapt Strateg Glob Chang 23(2):231-255

Clifford J (2000) Taking identity politics seriously: ‘The contradictory, stony ground...' In: Gilroy P, Grossber L, McRobbie A (eds) Without guarantees: in honour of Stuart Hall. Verso, London, pp 94-112

Cline EH (2015) 1177 BC: the year civilization collapsed. Princeton University Press, Princeton

Colette A (2007) Case studies on climate change and World Heritage. UNESCO Publishing, Paris

Cooper J, Sheets P (2012) Surviving sudden environmental change. University Press of Colorado, Boulder

DeSilvey C (2017) Curated decay: heritage beyond saving. University of Minnesota Press, Minneapolis

Dugmore AJ, Keller C, McGovern TH (2007) Norse Greenland settlement: reflections on climate change, trade, and the contrasting fates of human settlements in the North Atlantic islands. Arctic Aanthropol 44(1):12-36

Fatorić S, Seekamp E (2017a) Are cultural heritage and resources threatened by climate change? A systematic literature review. Clim Chang 142:227-254

Fatorić S, Seekamp E (2017b) Securing the future of cultural heritage by identifying barriers to and strategizing solutions for preservation under changing climate conditions. Sustainability 9(11):2143

Fatorić S, Seekamp E (2018) A measurement framework to increase transparency in historic preservation decision-making under changing climate conditions. J Cult Herit 30:168-179

Ferraby R (2015) Narratives of change on the Jurassic Coast World Heritage Site. In: Harvey DC, Perry J (eds) The future of heritage as climates change: loss, adaptation and creativity. Routledge, Abingdon, pp 25-42

Fisher CT, Hill JB, Feinman GM (eds) (2009) The archaeology of environmental change: socionatural legacies of degradation and resilience. University of Arizona Press, Tuscan

Folke C, Carpenter S, Walker B, Scheffer M, Chapin T, Rockström J (2010) Resilience thinking: integrating resilience, adaptability and transformability. Ecol Soc 15(4):20

Graham B (2011) Sharing space? Geography and politics in post-conflict Northern Ireland. In: Meusburger P, Heffernan M, Wunder E (eds) Cultural memories: the geographical point of view. Springer, Dordrecht, pp $87-100$

Gunderson LH, Holling CS (eds) (2002) Panarchy: understanding transformations in human and natural systems. Island Press, Covelo

Gunderson LH, Holling CS, Pritchard L, Peterson GD (2002) Resilience of large-scale resource systems. In: Gunderson LH, Pritchard L (eds) Resilience and the behaviour of large-scale systems. Island Press, Washington, pp 3-20

Guzman P, Fatorić S, Ishizawa M (2020) Monitoring climate change in World Heritage Properties: evaluating landscape-based approach in the State of Conservation system. Climate 8(3):39. https://doi.org/10.3390 /cli8030039

Hald M (2009) Past climate change and perspectives for archaeological research: examples from Norway, Svalbard, and adjoining seas. Arct Anthropol 46(1-2):8-16

Harvey D (2012) Emerging landscapes of heritage. In: Howard P, Thompson I, Waterton E (eds) The Routledge companion to landscape studies. Routledge, Abingdon, pp 152-165

Harvey DC, Perry J (2015) Heritage and climate change: the future is not the past. In: Harvey DC, Perry J (eds) The future of heritage as climates change: loss, adaptation and creativity. Routledge, Abingdon, pp $3-21$

Heilen M, Altschul JH, Lüth F (2018) Modelling resource values and climate change impacts to set preservation and research priorities. Conserva Manage Archaeologic Sites 20(4):261-284

Henderson M, Seekamp E (2018) Battling the tides of climate change: the power of intangible cultural resource values to bind place meanings in vulnerable historic districts. Heritage 1(2):220-238

Holling CS (1973) Resilience and stability of ecological systems. Annu Rev Ecol Syst 4:1-23

Holling CS (1996) Engineering resilience versus ecological resilience. In: Schulze PC (ed) Engineering within ecological constraints. National Academy Press, Washington, pp 31-44

Holling CS, Gunderson LH, Ludwig D (2002) In quest of a theory of adaptive change. In: Gunderson LH, Holling CS (eds) Panarchy: understanding transformations in human and natural systems. Island Press, Washington, pp 3-22

ICCROM. (2015). People-centered approaches to the conservation of cultural heritage: living heritage. Rome, IT: International Centre for the Study of the Preservation and Restoration of Cultural Property (ICCROM)

ICOMOS. (2011). Guidance on heritage impact assessments for cultural World Heritage properties. Paris, France 
ICOMOS. (2019). The future of our pasts: engaging cultural heritage in climate action. Climate Change and Heritage Working Group, Heritage and Climate Change Outline, Paris, France. Last accessed August 13, 2019 from: https://indd.adobe.com/view/a9a551e3-3b23-4127-99fd-a7a80d91a29e

ICOMOS. (2008). Québec declaration on the preservation of the spirit of place. Québec, Canada

Janssen J, Luiten E, Renes H, Stegmeijer E (2017) Heritage as sector, factor and vector: conceptualizing the shifting relationship between heritage management and spatial planning. Eur Plan Stud 25(9): 1654-1672

Jokilehto, J. (2006). Considerations on authenticity and integrity in world heritage context. City \& Time, 2(1), [online]: http://www.ceci-br.org/novo/revista/docs2006/CT-2006-44.pdf

Khalaf RW (2017) A viewpoint on the reconstruction of destroyed UNESCO Cultural World Heritage Sites. Int J Herit Stud 23(3):261-274

Krauß W (2015) Heritage and climate change: a fatal affair. In: Harvey DC, Perry J (eds) The future of heritage as climates change: loss, adaptation and creativity. Routledge, Abingdon, UK, pp 43-61

Labadi S (2013) UNESCO, cultural heritage, and outstanding universal value: value-based analyses of the world heritage and intangible cultural heritage conventions. Altamira Press, Lanham, MD

Lafrenz Samuels K (2018) Mobilizing heritage: anthropological practice and transnational prospects. University of Florida Press, Gainesville, FL

Larsen PB (2018) Human rights, wrongs and sustainable development in World Heritage. In: Larsen PB, Logan W (eds) World Heritage and sustainable development: new directions in World Heritage management. Routledge, Abingdon, pp 120-133

Laugrand F, Crépeau RR (2015) Shamanisms, religious networks and empowerment in Indigenous societies of the Americas. Anthropologica 57(2):289-298

Markham, A., Osipova, E., Lafrenz Samuels, K., \& Caldas, A. (2016). World heritage and tourism in a changing climate. United Nations Environment Programme, Nairobi, Kenya and United Nations Educational, Scientific and Cultural Organization, Paris, France

Markevičiene J (2012) The spirit of the place-the problem of (re) creating. J Archit Urban 36(1):73-81

Marzeion B, Levermann A (2014). Loss of cultural world heritage and currently inhabited places to sea-level rise. Environ Res Lett 9(3):034001

McAnany PA, Yoffee N (2010) Questioning collapse: human resilience, ecological vulnerability, and the aftermath of empire. Cambridge University Press, Cambridge

Mendes Zancheti S, Tone Ferreira Hidaka L (2011) Measuring urban heritage conservation: theory and structure (part 1). J Cult Herit Manage Sustain Develop 1(2):96-108

Meskell L (2014) States of conservation: protection, politics, and pacting within UNESCO's World Heritage Committee. Anthropol Q 87(1):217-243

Meskell L (2013) UNESCO's World Heritage Convention at 40: challenging the economic and political order of international heritage conservation. Curr Anthropol 54(4):483-494

Meskell L (2002) Negative heritage and past mastering in archaeology. Anthropol Q 75(3):557-574

Mezirow J (1991) Transformative dimensions of adult learning. Jossey-Bass, San Francisco

Middleton GD (2012) Nothing lasts forever: environmental discourses on the collapse of past societies. J Archaeol Res 20(3):257-307

Nishikawa, E. (n.d.). Earthquake as heritage-examples from Japan. Retrieved on August 9, 2019 from: https:/www.iccrom.org/projects/earthquake-heritage-examples-japan

Perry J (2011) World Heritage hot spots: a global model identifies the 16 natural heritage properties on the World Heritage List most at risk from climate change. Int J Herit Stud 17(5):426-441

Perry, J., and Falzon, C. (2014). Climate change adaptation for natural world heritage sites: a practical guide. World Heritage Papers Series, no. 37, Paris, France: United Nations Educational, Scientific and Cultural Organization (UNESCO), 88pp

Poulios I (2010) Moving beyond a values-based approach to heritage conservation. Conserva Manage Archaeologic Sites 12(2):170-185

Poulios I (2014) Discussing strategy in heritage conservation: living heritage approach as an example of strategic innovation. J Cult Herit Manage Sustain Develop 4(1):16-34

Reeder-Myers LA (2015) Cultural heritage at risk in the twenty-first century: a vulnerability assessment of coastal archaeological sites in the United States. J Island Coastal Archaeol 10(3):436-445

Reimann L, Vafeidis AT, Brown S, Hinkel J, Tol RS (2018) Mediterranean UNESCO World Heritage at risk from coastal flooding and erosion due to sea-level rise. Nat Commun 9(1):4161

Rockman M, Morgan M, Ziaja S, Hambrecht G, Meadow A (2016) Cultural resources climate change strategy. Cultural Resources, Partnerships, and Science and Climate Change Response Program, National Park Service, Washington

Rössler M (2006) World Heritage cultural landscapes: a UNESCO flagship programme 1992-2006. Landsc Res 31(4):333-353 
Rotherham ID (2013) Concluding thoughts on the implications of cultural severance on landscapes, ecology and people. In: Rotherham ID (ed) Cultural severance and the environment: the ending of traditional and customary practice on commons and landscapes managed in common. Springer, Dordrecht, pp 433-441

Sesana E, Gagnon A, Bertolin C, Hughes J (2018) Adapting cultural heritage to climate change risks: perspectives of cultural heritage experts in Europe. Geosciences 8(8):305

Settis S (2016) If Venice dies. New Vessel Press, New York

Smit B, Pilifosova O, Buron I, Challenger B, Huq S et al (2001) Adaptation to climate change in the context of sustainable development and equity. In: McCarthy JJ, Canziani O, Leary NA, Dokken DJ, White KS (eds) TAR climate change 2001: impacts, adaptation and vulnerability (pp.877-912). IPCC Working Group II. Cambridge University Press, Cambridge

Smith L (2006) Uses of heritage. Routledge and Taylor \& Francis Group, London

Tengberg A, Fredholm S, Eliasson I, Knez I, Saltzman K, Wetterberg O (2012) Cultural ecosystem services provided by landscapes: assessment of heritage values and identity. Ecosys Serv 2:14-26

Thornton TF, Manasfi N (2010) Adaptation-genuine and spurious: demystifying adaptation processes in relation to climate change. Environ Soc 1(1):132-155

Turney CS, Baillie M, Palmer J, Brown D (2006) Holocene climatic change and past Irish societal response. J Archaeol Sci 33(1):34-38

UNESCO, ICCROM, ICOMOS, IUCN (2010) Managing disaster risks for World Heritage. UNESCO World Heritage Center, Paris

UNESCO, ICCROM, ICOMOS, IUCN (2013) Managing cultural World Heritage. UNESCO World Heritage Centre, Paris

UNESCO. (2015). Policy document for the integration of a sustainable development perspective. Processes of the World Heritage Convention Adopted by the General Assembly of States Parties to the World Heritage Convention, 20th session. Paris, FR. Accessed May 31, 2019: https://whc.unesco.org/document/156000

Walker B, Holling CS, Carpenter S, Kinzig A (2004) Resilience, adaptability and transformability in socialecological systems. Ecol Soc 9(2):5

Watson JEM, Dudley N, Segan DB, Hockings M (2014) The performance and potential of protected areas. Nature 515:67-73

Wijesuriya G, Thompson J, Court S (2017) People-centered approaches: engaging communities and developing capacities for managing heritage. In: Chitty G (ed) Heritage, conservation and communities: engagement, participation and capacity building. Routledge, New York, NY, pp $34-49$

Xiao X, Seekamp E, van der Burg MP, Eaton M, Fatorić S, McCreary A (2019) Optimizing historic preservation under climate change: decision support for cultural resource adaptation planning in national parks. Land Use Policy 83:379-389

Yaeger J, Hodell DA (2008) The collapse of Maya civilization: assessing the interaction of culture, climate, and environment. In: Sandweiss D, Quilter J (eds) El Niño, catastrophism, and culture change in ancient America. Dumbarton Oaks, Washington, pp 187-242

Publisher's note Springer Nature remains neutral with regard to jurisdictional claims in published maps and institutional affiliations.

\section{Affiliations}

\section{Erin Seekamp ${ }^{1} \cdot{\text { Eugene } \mathrm{Jo}^{2}}^{2}$}

1 Department of Parks, Recreation and Tourism Management, Campus Box 8004, North Carolina State University, Raleigh, NC 27695, USA

2 World Heritage Leadership Programme, International Centre for the Study of the Preservation and Restoration of Cultural Property (ICCROM), Rome, Lazio, Italy 